\title{
The knowledge and practices of primary care givers regarding home-based care of HIV/AIDS children in Blantyre (Malawi).
}

\author{
EW Zimba, M.Sc (Nursing), University of the Witwatersrand \\ PA Mclnerney, PhD, Department of Nursing Education, University of the Witwatersrand
}

\section{Abstract}

Knowledge is one of the major factors that promotes adherence to treatment regimens. With the current trends worldwide of home and community-based services for the management of HIV/AIDS patients, knowledge of care givers about the home care of these patients will determine the success of the programs. The purpose of this descriptive study was to explore the knowledge and practices of primary care givers of HIV/AIDS children in the provision of home care services. In this study an attempt was made to describe the factors which are associated with knowledge. Thirty-six primary care givers were randomly selected from three major home based care centres in Blantyre City, Malawi. A structured interview schedule was used to collect data. Data were analysed manually and by computer, using the Statistical Package for Social Science (SPSS).

The findings revealed a gap in knowledge since in many instances taking a child to the hospital for the management of minor ailments was the action of choice, thus perpetuating the problem of overburdening hospital resources. Lack of prior preparation for home based care was found to be the major factor contributing to the lack of knowledge. Recommendations proposed include the need to put into place mechanisms that will ensure that all the primary care givers are adequately prepared in good time for home care service. Ensuring regular home visits was also thought to be helpful for efficient and effective supervision and reinforcement of information given to fill the gaps in knowledge wherever necessary.

\section{Uittreksel}

Kennis is een van die belangrike faktore wat verseker dat pasiente behandelingsvoorskrifte nakom. Met die huidige neigings wêreldwyd van tuis- en gemeenskapdiens in die versorging van MIV/VIGS pasiënte, is die kennis van die versorger oor tuisversorging 'n faktor wat die sukses van die tuisprogram sal beinvloed. Die doel van hierdie beskrywende studie was om die kennis van primêre versorgingswerkers oor die verskaffing van tuisversorging vir MIV/VIGS kinders, vas te stel. In hierdie studie is ' $n$ poging aangewend om die faktore te beskryf wat met kennis verband hou. Ses-en-dertig primêre versorgingswerkers was na willekeur van drie tuisversorging sentrums in Blantyre. Malawi gekies. 'n Gestruktureerde onderhoud-skedule was gebruik om data te versamel. Die data was met hand en met 'n rekenaar geanaliseer. Die "Statistical Package for Social Science (SPSS)" program was gebruik vir hierdie analise.

Die bevindinge het 'n gaping in die kennis van versorgingwerkers openbaar. In baie instansies het die versorgingswerkers verkies om pasiënte vir geringe ongesteldhede na 'n hospitaal te neem. As gevolg hiervan is die probleem van oorlading van hospitaal-hulpbronne vererger. Die gebrek aan voorbereiding van versorgingswerkers vir tuisversorging was een van die faktore wat bygedra het tot hulle swak kennis. Na aanleiding van die navorsing word aanbeveel dat 'n program daargestel word om te verseker dat versorgingwerkers voldoende opgelei word vir tuisversorging. Gereelde huisbesoeke word ook beskou as van waarde om bekwame en effektiewe toesig te verseker en om in die gapings in bestaande kennis aan te vul.

\section{Introduction}

Over the last two decades the increasing incidence of human immunodeficiency virus (HIV) infection, the causative agent of the human immunodeficiency syndrome (AIDS), has emerged as one of the most serious public health problems throughout the world and is expected to continue into the next decades (Chinn \& Mann, 1998). The problem is growing at an alarming rate in Malawi. As of November 1998, according to AIDS Care (1999), over a million people were infected with the virus and 50,975 cumulative number of AIDS cases were reported. The Malawi Ministry of Health and Population (1993), pointed out that in 1990 AIDS caused an excess of infant mortality rate of
17 per 1,000 live births in the under ones, and 39 per 1,000 in those under three years than would be the case if HIV was not present.

The US Bureau of the Census (1997) estimated that by the year 2010 the infant mortality rate in Malawi will be $60 \%$ higher than expected without AIDS. Furthermore, Foster (1998) reported that nearly one out of four children in Malawi would die before his / her fifth birthday, with AIDS contributing to nearly one half of the mortality.

In children, HIV progresses rapidly to AIDS (Hansell, Hughes, Caliandro, Russo, Budin, Hartman \& Hernandez, 1998). These 
children experience impaired growth and are more vulnerable to illnesses than adults with HIV, owing to the immaturity of their immune system. As a result of recurrent infections these children are frequently hospitalized causing a greater workload for the Pediatric Department, demanding greater amounts of medical and nursing time.

As a result of the escalating global increase of the HIV / AIDS epidemic new trends in managing HIV / AIDS patients are focusing on increased dehospitalization, improved out patient treatment procedures and a growing emphasis on home and community-based services (Hellinger, 1988). Malawi has adopted this approach such that the health policy is emphasizing a move towards community care through home based care (HBC) services. Home based care refers to the provision of needed health services to patients and families at home. Home based care is advocated because of the following advantages:

- $\quad$ it is less expensive for families because problems such as transport to hospital, time spent in hospital visiting and ceratin costs are reduced.

- $\quad$ patients feel less isolated from family and friends and potentially feel psychologically and spiritually more supported, comforted and better able to cope.

- $\quad$ people prefer to face ill health or death in familiar surroundings rather than in a hospital ward.

- relatives are able to take care of patients while attending to other chores.

- $\quad$ home care permits better follow-up and is the best way to provide educational opportunities for personal messages about AIDS prevention.

- $\quad$ home based care helps to reduce the frequency and duration of hospital admissions and hence prevent over burdening of hospital facilities (Jackson \& Kerkhoven, 1995 and Olenja, 1999).

According to Playle \& Keeley (1998), adherence to prescribed therapy has been observed to be beneficial to the client as well as to the health care system in both health and economic matters. That is, it can prevent unnecessary illnesses and hospital re-admissions, enhance patients' outcomes and lessen the burden of care on the families. Lack of adherence to prescribed treatment has been found to be a major problem especially in life long conditions like HIV / AIDS (Caldwell, Mascola, Smith, Thomas, Maldonado, Parrott, Byers and Oxtoby, 1992). According to Vivian (1996), lack of knowledge or clear understanding of the treatment regimen is regarded as the major factor contributing to non-adherence.

Unfortunately, while increased numbers of HIV / AIDS children are discharged to home based care, there is no data about the knowledge and practices of the primary care givers. Home based care would prove worthless if care givers did not adhere to the prescribed care as a result of lack of knowledge on how to care for the HIV / AIDS children at home. A number of studies have researched the experience of care givers of children infected with HIV / AIDS (Caldwell et al, 1992; Caliandro \& Hughes, 1998 and Hansell, Highes, Caliandro, Russo, Budin, Hartman \& Hernandez, 1998), but there is nothing specifically on the knowledge of care givers on home care of children with HIV / AIDS in Malawi. The purpose of this research, therefore, was to determine the knowledge and practices of primary care givers of HIV / AIDS children under home based care services and to describe the factors that were associated with knowl- edge and practices. Thus, the following research question was posed:

What is the knowledge and practices of primary care givers on home care of HIV / AIDS children?

\section{Definition of terms}

For the purpose of this study the following definitions apply:

- home based care - this is the provision of needed health care by a primary care giver to a patient or family at home.

- home-based care centre - this is a centre that is located within the community where $\mathrm{HBC}$ health staff assist with home based care services.

- home-based care support groups - groups of people, usually from religious orders and occasionally from the community itself, who assist in identifying individuals with chronic diseases and refer them to the $\mathrm{HBC}$ centres for assessment and management.

- $\quad$ primary care giver - this is an informal caregiver that may be the biological mother or father, grandparents, friends, foster or adoptive parents who provide most of the care to the HIV/AIDS child at home.

\section{Research design}

A descriptive survey was used as the research design for this study because of its flexibility and broadness in scope. Furthermore, the survey method allowed the researchers to examine the characteristics, opinions and intentions of the sample by means of self-report (Polit \& Hungler, 1997).

The objectives of the study were to:

- $\quad$ obtain demographic information about the respondents, in particular, gender, marital status, age, highest education attended, religion, occupation and personal income;

- $\quad$ explore and describe respondents' knowledge regarding home-based care of HIV / AIDS children with respect to fever, diarrhea, pain, cough, mouth, throat and skin problems, general hygiene and prevention of diseases;

- $\quad$ explore and describe the respondents' practices of home-based care with respect to the keeping of appointments and attendance at health education sessions at the HBC Centres, and

- $\quad$ explore and describe relationships between the demographic variables and the knowledge and practices of the respondents.

\section{Population and Sample}

The population consisted of primary care givers of HIV / AIDS children aged from birth to 12 years and registered for a period not less than two months with the Home Based Care Centres in Blantyre City, Malawi. The study sample of 36 primary care givers was randomly selected.

\section{Research Instrument}

Since no existing tools could be found for the study the researchers constructed a new tool. The programme for the instruction of primary care givers provided the conceptual framework for the development of a structured interview schedule, 
comprising of 32 questions. Both closed and open-ended questions were used to allow the respondents opportunity to express their views.

The interview schedule was divided into four sections. The first section comprised of seven questions that facilitated the collection of the respondents' demographic data. This included gender, age, marital status, religion and the relationship to the child. Information regarding level of education, occupational status and annual income were also collected.

In the second section eleven questions pertaining to the knowledge and practices of the care givers on home care of the HIV / AIDS children were posed. These questions were based on the programme of instruction which is used in Malawi to instruct primary care givers in home based care.

The third section comprised of eight questions in which respondents were asked to assess their adherence to the health advice given on home care. Four of these questions were open ended and gave the respondents the opportunity to state what they liked most about the HBC service offered, what problems they faced and to offer suggestions for the improvement of the service.

The fourth section comprised of a short checklist in which four aspects were assessed, viz. the keeping of appointments, the frequency of illness of the child since registering with the home care centre, the conditions suffered by the child since registration with the centre and the number of times the child had been hospitalised since registering with the centre.

\section{Validity and reliability}

The interview schedule was subjected to face and content validity. Experts in the fields of HIV / AIDS and home based care were consulted. Based on their suggestions minor alterations were made to the wording of the questions. Given the high level of illiteracy in Malawi, an interview schedule was used to collect data, thus improving the reliability of the data collected. Furthermore, the interviews were all conducted by the same researcher (E. Z.). A pilot study, comprising of five care givers that were not included in the study, was conducted to ensure that questions were phrased correctly.

Ethical issues were taken into consideration and permission was sought and obtained from the relevant committees anc authorities.

\section{Data collection}

Data were collected over a period of four weeks. One of the researchers (E. Z.) visited the care givers in their homes. The number of care givers interviewed per day varied depending on distances between respondents. The interview lasted approximately 30 minutes and was conducted in Chichewa, the local language of the respondents.

\section{Results}

\section{Sample Characteristics}

The sample consisted of 36 primary care givers whose sociodemographic data are presented in Table 1. Almost all of the care givers were females. The majority were aged between 21
Table 1: Socio-demographic characteristics of the primary care givers $(n=36)$.

\begin{tabular}{|l|l|l|}
\hline Variable & $\mathbf{N}$ & $\mathbf{\%}$ \\
\hline Sex & 34 & 94.4 \\
Female & 2 & 5.6 \\
Male & & \\
\hline Age & 2 & 5.6 \\
$0-20$ & 17 & 47.2 \\
$21-40$ & 12 & 33.3 \\
$41-60$ & 5 & 13.9 \\
Above 60 & & \\
\hline Marital Status & 1 & 2.8 \\
Single & 18 & 50 \\
Married & 3 & 8.3 \\
Divorced & 0 & 0 \\
Separated & 14 & 38.9 \\
Widowed & & \\
\hline Education & 7 & 19.4 \\
No Formal Education & 8 & 22.2 \\
Std 1-5 & 20 & 55.6 \\
Std 6-8 & 1 & 2.8 \\
Secondary Education & 0 & 0 \\
College or higher & 24 & 66.7 \\
\hline Religion & & \\
C.C.A.P & 5 & 13.9 \\
Roman Catholic & 20 & 55.6 \\
Seventh Day Adventist & 4 & 11.1 \\
Pentecostal & 6 & 2.8 \\
Other & 16.7 \\
\hline Occupational Status & 19 & 36.3 \\
Housewife & & \\
Business & & 2.8 \\
Teacher (Nursery School) & & 5.6 \\
Farmer & & \\
Other ( One beggar and one & & \\
school drop out) & & \\
\hline Prior Preparation & & \\
Yes & & \\
No & & \\
\hline
\end{tabular}

and 60 years and most of them were married. Just over half, $55,6 \%(20)$, had attended formal education ranging between Std 6-8 (six to eight years of schooling). The majority of the care givers, 55,6\% (20) belonged to the Roman Catholic Church. Approximately one-half were doing some form of small-scale business and all of the care givers came from low-income families with an annual income of less than K20,000 (RI = $10 \mathrm{Ma}-$ lawi Kwacha).

Two-thirds, 66,7\% (24), of the care givers had received no prior preparation for the home care of the HIV / AIDS child. Their relationship to the sick child and the child's status are shown in Table 2. The biological mother took care of most of the children and just over half, $52,8 \%$ (19), of the children had lost one 
Table 2: Care giver's relationship with the child and the parental status of the children $(n=36)$.

\begin{tabular}{|l|c|c|}
\hline Variable & $\mathbf{N}$ & \% \\
\hline Relationship & & \\
Mother & 21 & 58.3 \\
Grandmother & 9 & 25 \\
Auntie & 3 & 8.4 \\
Father & 2 & 5.6 \\
Sister & 1 & 2.8 \\
\hline Status & & \\
Orphaned & 19 & 52.8 \\
Not orphaned & 17 & 47.2 \\
\hline
\end{tabular}

or both parents.

The majority of the families, $69,4 \%$ (25), were referred to the $\mathrm{HBC}$ through $\mathrm{HBC}$ support groups and only $27,8 \%$ (10) were referred by hospital institutions, while one family joined voluntarily. At the time of the interview most of the families had been registered with the $\mathrm{HBC}$ for a period not less than six months (see Table 3).

\section{Table 3: The period of registration with the HBC $(n=36)$}

\begin{tabular}{|l|r|c|}
\hline Period & N & \% \\
\hline 0-6 Months & 8 & 22.2 \\
\hline 6-12 Months & 18 & 50 \\
\hline 12-18 Months & 4 & 1.1 \\
\hline 18 or more Months & 6 & 16.7 \\
\hline TOTAL & 36 & 100 \\
\hline
\end{tabular}

The respondents were asked to name the conditions the children had suffered since registering with the HBC services. The results revealed that the majority, $80,6 \%$ (29), had suffered from a respiratory infection, $77,8 \%$ (28) fever, $52,8 \%$ (19) skin problems, $44,4 \%$ (16) diarrhea and a third, 33,3\% (12), oral thrush. Another third, 33,3\% (12), had suffered from malnutrition and very few, $11.1 \%(4)$ and $5,6 \%(2)$, had suffered from anemia and convulsions respectively.

\section{Knowledge of the care givers on the management of the minor ailments of HIV / AIDS children}

Eleven questions were asked that focused on the knowledge of the care givers on how to care for the HIV / AIDS children at home. Table 4 shows the actions and the frequency of the actions, taken by the care givers to address fever, diarrhea, pain, cough, mouth, throat and skin problems. Care givers were allowed to give multiple responses to this question and therefore $\mathbf{n}$ is not equal to 36 .
It is evident that the most frequent action taken in dealing with problems relating to the above mentioned minor ailments of HIV / AIDS in children was to take the child to the clinic. Yet in coping with pain in the child, taking the child to the clinic was not considered as an option. The most frequent action mentioned was the giving of painkillers.

\section{Comparison of knowledge against prior preparation for HBC}

Further analysis was carried out in an effort to determine whether prior preparation for home care of HIV / AIDS children was given to care givers who did nothing but take the child to the clinic for the management of fever, diarrhea, cough, mouth, throat and skin problems. The results demonstrated that the majorities were those who did not have any prior preparation for home care (see Figure 1).

A group analysis between the care givers who had received prior preparation and those who did not was done using the Fishers' Exact Test to determine if there was any significant difference between the two groups on specific areas of knowledge. The areas included the management of fever, diarrhea, pain, cough, mouth, throat and skin problems. No significant difference was found between the two groups on the management of pain. However, the results revealed significant differences between the groups on management of fever, diarrhea, cough, mouth, throat and skin problems. The level of significance considered acceptable was $\mathrm{p}<0,05$ (see Table 5).

\section{The respondents' own assessment of their degree of adherence to the management of minor ailments of HIV / AIDS in children}

The care givers were asked to describe their degree of adherence to the health advice given on home care of the minor ailments of HIV / AIDS children using a Likert Scale. The scale was as follows:

$0=$ None of the time;

$1=$ very seldom;

2 = less than half of the time;

$3=$ most of the time, and

$4=$ all of the time.

The majority, $55,5 \%-63,8 \%$, felt that they less than half of the times followed the HBC advice on the management of diarrhea, fever, pain, respiratory infection, mouth, throat and skin problems. This was in contrast to their perceptions of meeting the child's routine screening and follow-up appointment where the findings showed that $41,6-63,8 \%$ of the care givers felt that most of the time they followed the HBC advice given.

\section{Factors influencing the care givers compliant behaviour}

In general, all the care givers felt that they did not receive information on the home care of the HIV / AIDS children. However, specifically, $63,8 \%$ (23) and $11,1 \%$ (4), of the care givers felt that the lack of resources and the lack of information respectively, negatively affected their compliant behaviour, while $19,4 \%$ (7), $16,7 \%(6)$ and $8,3 \%$ (3) felt that the advice, the encouragement and the support they received respectively, posi- 
Table 4: Actions taken by the care givers to manage the minor ailments of HIV/AIDS in children

\begin{tabular}{|l|l|l|}
\hline Activity & N & $\%$ \\
\hline Management of fever & & \\
Take child to the clinic & 28 & 77.8 \\
Give Panadols or Aspirin & 22 & 61.1 \\
Give a cool bath & 13 & 36.1 \\
Wipe child with lukewarm water & 1 & 2.8 \\
\hline Management of Diarrhea & & \\
Take child to the clinic & 26 & 72.2 \\
Give plenty of fluids & 20 & 55.6 \\
Change and wash soiled linen as soon as they are soiled & 7 & 19.4 \\
Offer nutritious food more frequently than normal & 1 & 2.8 \\
\hline Management of Pain & & \\
Give Panadols or Aspirin & 23 & 63.9 \\
Provide diversional therapy & 6 & 16.7 \\
Change position & 1 & 2.8 \\
Other & 3 & 8.3 \\
\hline Management of Cough & & \\
Take child to the clinic & 35 & 97.2 \\
Place child in a well ventilated room & 12 & 33.3 \\
Provide adequate fluids & 12 & 33.3 \\
Advise child to spit into a container & 9 & 25 \\
Give throat soothing remedies & 5 & 13.9 \\
Provide nutritious food & 4 & 11.1 \\
Give painkillers & 3 & 8.3 \\
Give traditional medicine & 1 & 2.8 \\
\hline Management of Mouth and Throat Problems & 28 & 77.8 \\
Take child to the clinic & 13 & 36.1 \\
Provide mouth washes & 2 & 8.3 \\
Give painkillers & 1 & 2.6 \\
Apply prescribed medication & & 2.8 \\
Give soft nourishing diet & & \\
\hline Management of Skin Problems & & \\
Take child to the clinic & & \\
Bath child with soap and warm water & & \\
Apply prescribed skin lotion & & \\
Change position and massage pressure areas & & \\
\hline
\end{tabular}

and advice given on traditional medicine. Only one care giver stated that there was nothing that she liked about the activities of the HBC service.

\section{Problems faced with HBC services}

Most of the care givers, 55,6\% (20), mentioned the stopping of free food supplements as the major problem. Just under a third, 30,6\% (11), mentioned irregular home visits and $25 \%$ (9) mentioned the stopping of issuing free drugs during home visits as some of the major problems faced. Only $11,1 \%$ (4) mentioned inadequate supplies as one of the major problems faced with the $\mathrm{HBC}$ services.

\section{Care givers' suggestions on how to improve the HBC service offered}

The majority, $55,5 \%$ (20), of the care givers suggested that the HBC services should provide financial assistance. Of these twenty care givers, $36,1 \%$ (13), stated that the financial assistance could be in the form of a loan that could be used as capital for income generating activities (IGA), while $44,4 \%$ (16), stated that the HBC should continue to provide free drugs during home visits.

\section{Review of medical records}

All of the children had completed all of the immunizations against polio and measles and had received the BCG and DPT, but none had received any boosters. Most of them. $82,8 \%$ (24), had met the requirement for diagnostic tests. Just under two thirds of the care givers, $64 \%$ (16), had been able to take their children for medical review and $80 \%$ (16) had been able to meet the requirement to go to the clinic for a re-supply of drugs. These figures were calculated on those to whom it was applicable. Only $27,8 \%$ (10) had been able to attend health education sessions.

tively influenced their compliant behaviour.

\section{The most liked activities offered by the HBC service}

In order to identify the strengths of the HBC service the care givers were asked to state what they liked most about the HBC services offered. The majority of the care givers, 80,6\% (29), pointed out that what they liked most was the support and encouragement they received from the HBC staff. Less than half, $41,6 \%$ (15), stated that what they liked most was the food supplements they received, another $41,6 \%$ (15), liked most the home visits offered and $33,3 \%$ (12), liked most the free nursery school provided to their children. Very few, $2,7 \%$ (1) to $5,5 \%$ (2), mentioned spiritual help, assistance given on physical care
Almost all the care givers, $94,4 \%$ (34), stated that they would like to belong to the $\mathrm{HBC}$ services for as long as was necessary.

\section{Limitations of the study}

The following limitations were identified in this study:

- the choice of the City under study was based on nonprobability sampling which limits the generalization of the findings.

- the findings relate to a small sample size of only 36 primary care givers that may not be representative of the entire population of primary care givers in Blantyre City. 


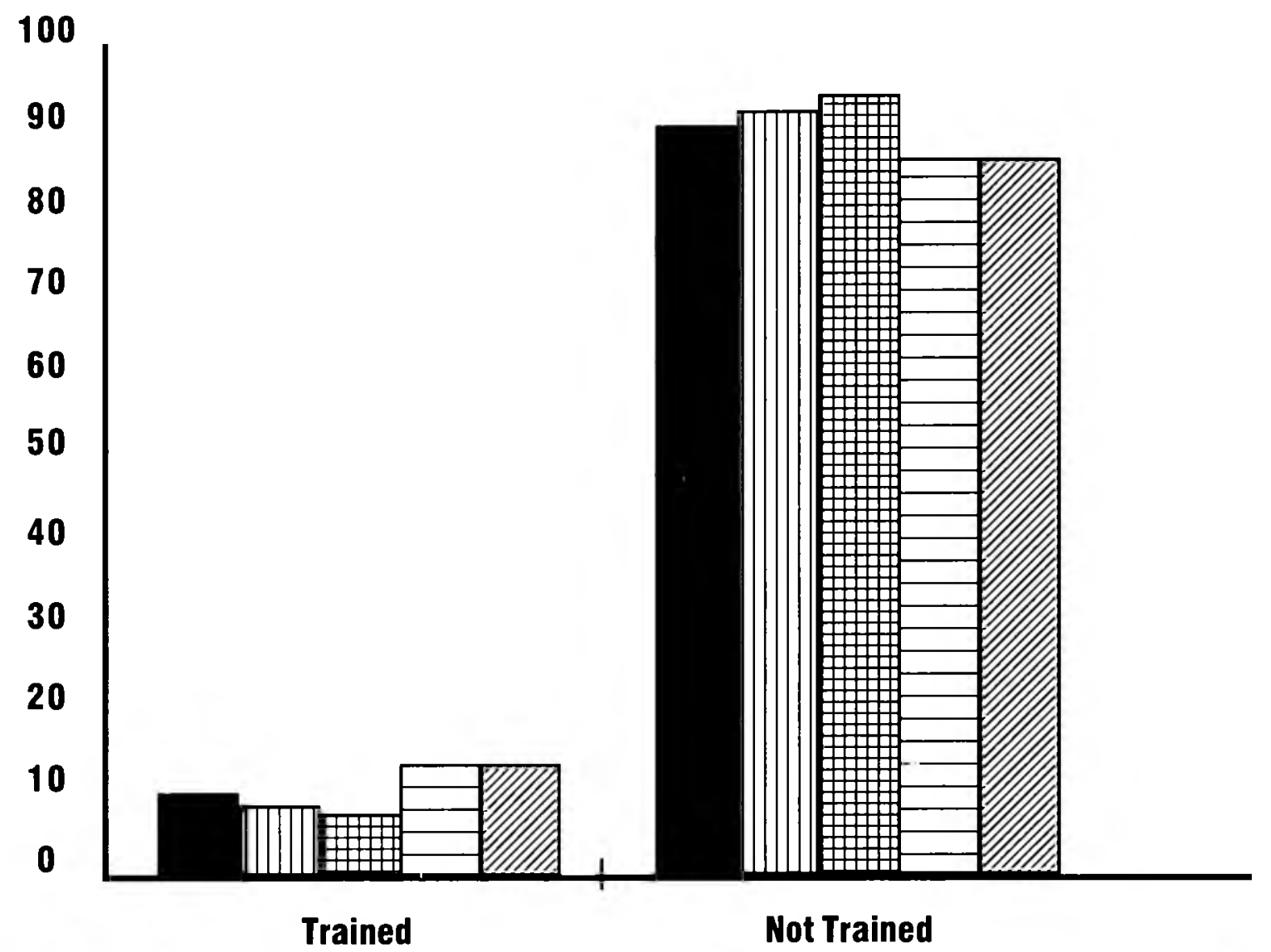

Fever
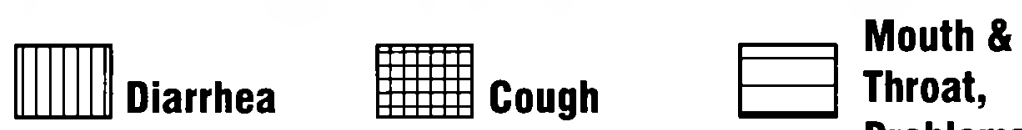
Problems

Skin problems
- the sample was drawn from HBC centres based on the evidence that the majority of clients who are already diagnosed to be HIV / AIDS infected use these centres. No conformation tests of the children were done hence generalizations from the findings should be made with caution.

- $\quad$ the results were formulated based on the care givers' recall and reliability.

\section{Discussion}

The findings of the study revealed that the care givers were predominantly women and all of them came from low-income families. This is consistent with Ngugi and Njenga (1995), who wrote that it is usually the women who are the most economically disadvantaged and yet have to bear the burden of care. Olenja (1999) pointed out that the demands of the HIV /AIDS patient are often high - emotionally, financially and in terms of time. Hence there is need to further analyse this issue in order to identify strategies to help boost the financial status of the care givers. It is unrealistic to expect them to provide efficient care if they do not have the resources.

The fact that $52,8 \%$ (19) of the children were orphans (had lost one or both parents) and just over a third, $41,7 \%$ (15), were cared for by someone other than their biological mother, has serious implications for the child's health. According to Foster (1998), in developing countries the mother of the child is con- sidered as the main primary health care worker. Therefore these children in the study may be at risk of poor health as a result of being cared for by someone other than the biological mother.

Even though the discharge system of HIV /AIDS patients is theoretically supposed to be mainly from the hospital institutions, the results of this study have demonstrated that the majority of the patients, $72,2 \%(26)$, were referred to the HBC services through HBC support groups. This is consistent with the findings of Sichinga's (1999) special study of home based care systems in Malawi. He found that in most instances the support groups used the community sources to find patients for $\mathrm{HBC}$ services. It is very likely that the care givers of such patients would not have been prepared for the responsibility of caring for the patient at home. Although there could be many plausible explanations for these observations, two of the most likely reasons could be that most of the hospitalized patients do not have their HIV status revealed to them and hence cannot be referred to the HBC services. Secondly, most of the hospital personnel lack skills in counselling patients for the HBC services. Therefore there is need for the government to further analyse the issue so as to identify strategies that can help improve the referral system of the patients from hospital institutions. This will assist in ensuring that education of the primary care givers begins at hospital level.

The findings reveal a gap in knowledge, since in many instances taking the child to the clinic, for the management of minor ail- 
Table 5: Fishers' exact two-tail test analysis on specific areas of knowledge between care givers with prior preparation and those without.

\begin{tabular}{|l|l|l|l|l|l|}
\hline $\begin{array}{l}\text { Action } \\
\text { Group }\end{array}$ & Yes & No & $\mathbf{n}$ & $\mathbf{P}$ & Value \\
\hline Giving the child a cool bath for fever & 1 & 9 & 3 & 12 & 0.001 \\
& 2 & 4 & 23 & 24 & \\
\hline Give plenty of fluids for diarrhea & 1 & 10 & 2 & 12 & 0.032 \\
\hline Changing and washing soiled linen as soon as soiled & 1 & 6 & 6 & 12 & \\
& 2 & 1 & 23 & 24 & 0.003 \\
\hline Providing frequent mouth washes with salty water for & 1 & 8 & 4 & 12 & \\
mouth and throat problems & 2 & 5 & 19 & 24 & 0.011 \\
\hline Giving painkillers for mouth and throat problems & 1 & 3 & 9 & 12 & \\
& 2 & 0 & 24 & 24 & 0.031 \\
\hline For skin problems cleaning with warm soapy water and & 1 & 7 & 5 & 12 & \\
for open wounds uses salty water & 2 & 1 & 23 & 24 & 0.001 \\
\hline Apply prescribed skin lotion for skin problems & 1 & 5 & 7 & 12 & \\
& 2 & 2 & 22 & 24 & 0.029 \\
\hline Providing adequate fluids for a cough & 1 & 8 & 4 & 12 & \\
\hline Providing throat soothing remedies for a cough & 1 & 4 & 8 & 12 & 0.007 \\
\hline Providing nutritious food to a child with a cough & 1 & 4 & 8 & 12 & \\
& 2 & 0 & 24 & 24 & 0.008 \\
\hline
\end{tabular}

Key : Group 1 = Caregivers who received prior preparation for $\mathrm{HBC}$

Group 2 = Caregivers who did not receive prior preparation for $\mathrm{HBC}$

ments, was the action of choice, thus perpetuating the problem of overburdening hospital resources. This lack of knowledge could be attributed to the fact that very few care givers had received prior preparation for the home management of these children. This was evidenced by the fact that the majority of the care givers who did nothing but take the child to the clinic for the treatment of minor ailments of HIV / AIDS in children were those who had received no prior preparation (see Tables 4 and 5).

Even though it is well known that training is crucial for the effectiveness of home care of HIV / AIDS children. the findings of this study have revealed that this is lacking at the family level. All the care givers in the study felt that they had not received adequate information. These findings have a number of implications for the training that is provided to these care givers by both the hospital institutions and the HBC centres. Considering that the majority of the care givers, $77,8 \%$ (28), were registered for a period of six months or more, if proper training is done, this should be an adequate period of time for care givers to master the recommended care policies. Therefore there is need to readdress the process of dissemination of information to the primary care givers so that appropriate strat- egies can be formulated. HBC centres should develop special training programs for the care givers that are referred by institutions other than the hospital so that they can be trained in the home care of their child as soon as possible after being registered at the $\mathrm{HBC}$ centre. Furthermore, the government and non-governmental organizations should work in collaboration to provide regular training sessions and refresher courses for the HBC volunteers so that the service delivery can be improved.

The other important finding was that the care givers were dependent on free materials and financial assistance. The need for free food supplements was emphasized by most of the care givers and therefore the government needs to identify strategies for the sustainability of food supplements to these families. Support of income generating activities also needs to be considered so as to improve the financial status of these care givers. In addition, $\mathrm{HBC}$ services should ensure regular home visits for proper supervision and reinforcement of information given.

The medical record review demonstrated that the care givers were better at attendance of follow-up appointments as com- 
pared with providing care at home. This is also in agreement with the care givers own assessment of their adherence to meeting the child's routine screening and follow-up appointments. However, it was disturbing to find that whilst care givers can attend the services for the administration of drugs and tests, health education sessions appear to be considered less important, as only $27,8 \%(10)$ had attended these. This is a serious problem and it defeats one of the major aims of $\mathrm{HBC}$ which is to promote AIDS awareness through health education of the families belonging to the HBC services. There is need to thoroughly examine the problem in order to identify appropriate strategies to improve the attendance at the sessions.

However it was encouraging to note that $94,4 \%$ (34) of the care givers would like to belong to the HBC program for as long as necessary.

\section{Recommendations}

Recommendations are made for practice, education and further research. These are as follows:

- for practice:

- $\quad$ systems for referral of patients from hospital institutions to HBC services need to be improved so that education of the primary care giver can commence in the hospital.

- $\quad$ the HBC service should ensure regular home visits for supervision and reinforcement of information given.

- $\quad$ strategies need to be formulated to provide booster immunizations.

- $\quad$ strategies need to be identified for the sustainability of food supplements to these families.

- for education:

- $\quad$ care givers should be fully informed of the diagnosis and the nature of medical treatments and care that the child will require.

- $\quad$ care givers should be given specific guidelines in simple terms for the procedures to be used when caring for the child.

- $\quad$ care givers should be informed of the pros and cons of current therapies.

- $\quad$ HBC centres should develop special training programs for care givers that are referred by institutions other than the hospital so that they can be trained about home management of the child as soon as possible after being registered with the centre.

- government and non-governmental organizations should work in collaboration to provide regular training sessions and refresher courses for the HBC volunteers.

- for further research:

- there is need to conduct a similar study using a larger sample.

\section{Conclusion}

Although HBC programs have been found to be an economical, appropriate and effective way of providing care to HIV / AIDS children, there is need to readdress the issue of lack of knowledge through a rigorous training program for the volunteers and the primary care givers. The emphasis should be to ensure that the primary care givers are trained adequately and in good time because they are the ones who are invested with the responsibility to provide the bulk of care at home without which the HBC programs would prove worthless. 
AIDS CARE 1999: Editorial. WHO Global AIDS Statistics. 12 (2) :239-248.

CALDWELL, BM; MASCOLA, L; SMITH,W; THOMAS, P; HSU, H; MALDONADO, Y; PARROTT, R; BYERS, R; OXTOBY, M \& PEDIATRIC SPECTRUM OF DISEASE CLINICAL CONSORTIUM 1992: Biologic, Foster and Adoptive Parents: Care givers of children exposed perinatally to Human Immunodeficiency Virus in the United States. Pediatrics $, 10(4): 603-607$.

CALIANDRO, G \& HUGHES, C 1998: The Experience of Being a Grandmother who is the Primary Care Giver of her HIVPositive Grandchild. Nursing Research. 47 (2) : 107-113.

CHIN, J \& MANN, J 1998: Global Surveillance and Forecasting of AIDS. World Health Organization. 76 (5) : 429-435.

FOSTER, G 1998: Today's Children - Challenges to Child Health promotion in Countries With Severe AIDS Epidemics. AIDS Care (Supplement). 10:s17-s23.

HANSELL, PS; HUGHES, CB; CALIANDRO, G; RUSSO,P; BUDIN, WC; HARTMAN, B \& HERNANDEZ, VC 1998: The Effect of a Social Support Boosting Intervention on Stress, Coping and Social Support in Care Givers of Children With HIV/AIDS. Nursing Research. 47 (2) : 79-85.

HELLINGER, F 1988: Forecasting the Personal Medical Care Costs of AIDS For 1988 Through 1991. Public Health Report. 103:309-323.

JACKSON, H \& KERKHOVEN, R 1995: Developing AIDS Care in Zimbabwe : A Case For Residential Community Centres? AIDS Care. 7 (5) : 663-673.

MALAWI MINISTRY OF HEALTH AND POPULATION (MOHP) 1993: Analysis of Poverty in Malawi. UNICEF and UNDP, Lilongwe : National Statistics Office.

NGUGI, E \& NJENGA, E 1995: Integrating Community-Based AIDS Care Into Existing Urban Health Units in Nairobi, Kenya : A Feasibility Study. Consultancy Report. WHO : Nairobi.

OLENJA, JM 1999: Assessing Community Attitude Towards Home-Based Care for People with AIDS (PWAS) in Kenya. Journal of Community Health. 24 (3):187-199.

PLAYLE, JF \& KEELEY 1998: Non-compliance and Professional Power. Joumal of Advanced Nursing . 27 (2) : 304-311.

POLIT, DF \& HUNGLER, BP 1997: Essentials of Nursing Research Methods, Appraisal and Utilization, $4^{\text {th }}$ edition. Philadelphia : JB Lippincott Company.

SICHINGA, KW 1999: Special Study on Home-Based Care Systems in Malawi. ( Unpublished paper.)

US BUREAU OF CENSUS 1997: The Demographic Impacts of HIV/AIDS - Perspective From the World population Profile :
1996. Washington D.C. : International Programs Centre Population Division.

VIVIAN, JB 1996 : Respite Care for HIV-Affected Families. Social Work in Pediatrics. 21 (1) : 55-67. 